
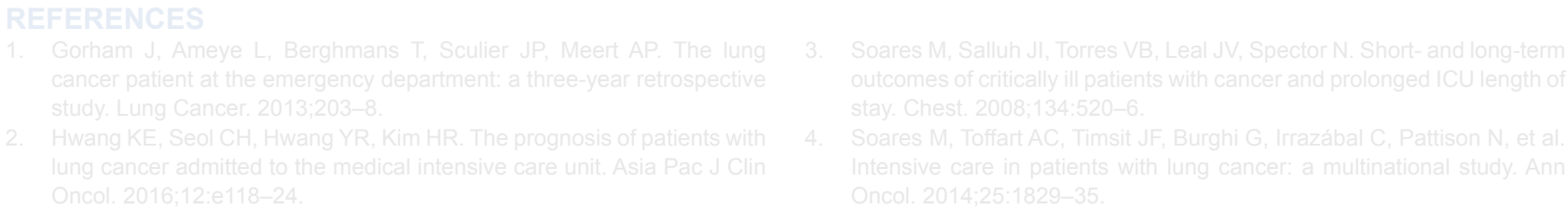

\section{Definição do Conceito de Morte Antecipada em Português}

\section{Definition of the Concept of Hastened Death in Portuguese}

Palavras-chave: Atitude Frente à Morte; Eutanásia; Suicídio Assistido/psicologia

Keywords: Attitude to Death; Euthanasia; Suicide, Assisted/ psychology

\section{Ao Editor,}

Em Portugal é frequente a utilização do termo morte assistida. Neste âmbito, considera-se que uma pequena nota sobre o tema é merecida.

Terá sido Bacon (1605) o primeiro a referir-se à eutanásia em contexto médico. Ao longo dos anos, as atitudes perante a eutanásia têm mudado, aumentando o número de países ou estados que legalizaram a sua prática. ${ }^{1}$ Com essa evolução, o conceito foi-se desenvolvendo, surgindo distinções referentes à sua prática, como a eutanásia voluntária, não voluntária, involuntária, ativa e passiva, e o suicídio assistido. O termo morte assistida ou morte medicamente assistida tem sido frequentemente utilizado quando se fala de eutanásia ou suicídio assistido. Veja-se o caso do Canadá em que a legislação sobre a eutanásia e o suicídio assistido intitula-se Assistência Médica na Morte (tradução dos autores). Segundo Downie, ${ }^{2}$ a morte assistida é um termo abrangente e pressupõe um ato ou omissão intencional de uma pessoa sobre a outra e inclui as várias formas de eutanásia e o suicídio assistido. Entende-se que existe uma falta de rigor no termo morte assistida, uma vez que pode apontar para um procedimento que não implique uma antecipação do momento da morte. Na verdade, a morte deseja-se assistida, seja medicamente ou familiarmente, sendo normalmente lamentada a ideia de uma pessoa morrer sozinha. ${ }^{3}$ Assim, os autores entendem que o conceito 'morte antecipada' será mais rigoroso e esclarecedor quando se faz referência a qualquer tipo de eutanásia e ao suicídio assistido. Implica uma ação ou omissão de uma pessoa sobre a outra, com o objetivo de antecipar o momento da morte de alguém.

A exclusão do termo 'medicamente' neste novo conceito não visa desresponsabilizar ou excluir os médicos no processo de antecipação da morte, nem retirar a discussão da esfera da medicina. Contudo, a controvérsia sobre o tema não se centra na participação ou não dos médicos, mas sim na possibilidade de se antecipar a morte de alguém a seu pedido. Nesse sentido, a unificação deste fenómeno num único termo de 'morte antecipada', em substituição da 'morte assistida' poderá contribuir para uma maior clarificação sobre aquilo que está em causa e deste modo ajudar as pessoas na sua compreensão.

Salienta-se que o termo 'morte antecipada' não pretende ser um elemento dissuasor e perturbador de uma discussão responsável sobre a eutanásia e o suicídio assistido. Este termo tomou forma devido à preocupação dos autores com o rigor científico.

\title{
REFERÊNCIAS
}

1. Youngner SJ, Arnold MR, editors. The Oxford Handbook of Ethics at the End of Life. Oxford: Oxford University Press; 2016.

2. Downie J. Dying justice: a case for decriminalizing euthanasia \& assisted

suicide. Toronto: University of Toronto Press; 2004.

3. Seale C. Media constructions of dying alone: a form of "bad death." Soc Sci Med. 2004;58:967-74.

Sílvia MARINA ${ }^{1,2}$, Inês COSTA-MAIA ${ }^{1,3}$, Miguel RICOU $\bigotimes^{1,2}$

1. Faculdade de Medicina. Universidade do Porto. Porto. Portugal.

2. CINTESIS - Centro de Investigação em Tecnologias e Serviços de Saúde. Porto. Portugal.

3. Plataforma Europeia Wish to Die. Porto. Portugal.

$\bowtie$ Autor correspondente: Miguel Ricou. mricou@med.up.pt

Recebido: 26 de maio de 2019 - Aceite: 28 de maio de 2019 | Copyright @ Ordem dos Médicos 2019

https://doi.org/10.20344/amp.12359 